\title{
THE INTERNATIONALISATION OF INDIAN MULTINATIONALS: DETERMINANTS OF EXPANSION THROUGH ACQUISITIONS
}

\begin{abstract}
In recent years, there is an increasing number of papers focusing on the internationalisation process of Indian multinationals (MNCs). However, there is still a gap in understanding the determinants of their outward foreign direct investment (FDI) decisions. Thus, this paper analyses the factors influencing the choice between FDI modes by Indian firms. Our findings show that industry technological intensity, host country risk, host market attractiveness, previous international experience and the volume of exports from India to the host country, are determining factors of the choice between acquisitions and greenfields.
\end{abstract}

\section{Keywords}

Indian MNCs, FDI, greenfields, acquisitions.

\section{Introduction}

MNCs from emerging markets are playing an increasingly important role in this new century, not because they are a new phenomenon, but for the strong growth rate they have recorded since the 1990s (UNCTAD, 2010). The rising international presence of these MNCs requires a greater attention to how they behave. Understanding the profile of emerging market MNCs, the nature of their strategies and the consequences of their actions may have significant implications for the development of home and host economies (Gammeltoft, Pradhan \& Goldstein, 2010).

According to World Bank data for 2010, India is the world's third-largest emerging economy, behind China and Brazil. On the one hand, investment in India has increased most particularly since the $1990 \mathrm{~s}$, when changes were introduced that made it easier for the country to open up to the outside world. On the other hand, outward FDI by Indian firms has grown considerably thanks to the liberalisation of the policy regime and the greater access to financial markets. These investments would amount to an average of approximately US\$ 1 billion a year between 1995 and 2005, and to US\$ 14.6 billion in 2010 (UNCTAD, 2011). 
Since 2003, outward investment policy reforms in India have increased acquisition activities by Indian MNEs (Buckley, Forsans \& Munjal, 2009). This is one of the main options chosen by large Indian firms to go abroad. This establishment mode has allowed firms from emerging markets to access strategic resources (Capron, Dussauge \& Mitchell, 1998; Gubbi, Aulakh, Ray, Sarkar \& Chittoor, 2010; Kumar, 2007). Many studies have analysed this topic from various perspectives: some have focused on acquisitions as a way of reducing competitors' intensity and increasing market power (Stigler, 1964), whereas others suggest that acquisitions led to increased scale efficiencies (Dutz, 1989; Jensen, 1986). From a strategic management perspective, recent studies have focused on a range of issues, such as the motives for acquisitions and the pre-acquisition and post-acquisition performance of the acquired and acquiring firms (Aybar \& Ficici, 2009; Chatterjee \& Lubatkin, 1990; Chatterjee \& Wernerfelt, 1991; Demirbag, Tatoglu \& Glaister, 2008; Gubbi et al., 2010; Kumar \& Bansal, 2008; Seth, 1990; Slangen, 2006).

Because India is an emerging economy with a changing institutional environment, the country's situation is an interesting framework from which to examine the influence of certain variables on international decisions made by MNCs. Very little is known about strategies of Indian MNCs as compared to MNCs from developed economies (Buckley et al., 2009; Kumar, 2007). This paper follows recent work examining the factors that lead Indian firms to enter foreign markets through acquisitions, compared with the option of a start-up in the foreign country using greenfield investments (Buckley, Forsans \& Munjal, 2012; Duanmu \& Guney, 2009; Nayyar, 2008; Pradhan \& Abraham, 2004; Rangan \& Parriño, 2008; Singh, 2009). More specifically, our aim is to answer the following question: What external and internal factors lead Indian MNCs to enter a foreign market by acquiring existing firms? This will determine whether Indian MNCs, with less industrial development, infrastructure and capacity, display the same patterns of behaviour as MNCs from other countries.

From a theoretical point of view, emerging economies are a new context with their own characteristics in terms of how their resources are configured when compared with developed countries; for example, firms from developing countries do not usually have the same ownership advantages as large MNCs from developed economies. This means that traditional theories alone cannot be used to study the internationalisation process carried out by emerging market MNCs (Demirbag, Glaister \& Tatoglu, 2007; Gammeltoft, et al., 2010; 
Gaur \& Kumar, 2009). Thus, a multi-perspective approach appears to be more appropriate to analyse the determining factors of establishment mode choice of emerging Indian MNCs. In doing so, we integrate the existing literature on internationalisation with the institutional perspective.

The rest of the paper is structured as follows. The following section sets out different internationalisation theories to propose various hypotheses relating to the factors influencing establishment mode choice. This is followed by a description of the methodology used and the results obtained. Those results are then discussed and compared with the existing literature on acquisitions. Finally, the conclusions and future lines of research are presented.

\section{Theory and hypotheses}

Many international business researchers have focused on entry mode choice. A firm that decides to expand into foreign markets must choose between keeping and sharing control of its subsidiaries (Arregle, Hebert \& Beamish, 2006). It must also decide whether to acquire an existing local firm, making an acquisition, or opt for a start-up a new venture, making a greenfield investment (Barkema \& Vermeulen, 1998; Hennart \& Park, 1993). Cross-border acquisitions have been increasing rapidly over recent years. According to the UNCTAD (2011), the value of acquisitions deals increased by 36 per cent in 2010, while greenfield investments declined that year.

Dunning's Eclectic Paradigm sets out three factors that affect how firms choose to internationalise their operations (Dunning, 1988, 1993): ownership advantages, location advantages and internalisation advantages. This is the most commonly used approach in the existing literature on FDI of Indian MNCs (Anwar, Hasse \& Rabbi, 2008). This approach highlights firms' specific advantages and country's specific advantages. The internationalisation of firms from India is due to the accumulation of a series of advantages relating to ownership, government liberalised policies and locational advantages of the host market (Anwar et al., 2008).

In terms of resources, acquisitions are a mechanism generally used to exchange capabilities that would otherwise be impossible to use efficiently (Capron et al., 1998; Seth, 1990). The entry mode choice will depend on the relationship between the firms's resource base and the new resources required by the market (Lee \& Lieberman, 2010). This means that 
when the firm decides to enter another country, it can use its firm-specific capabilities in a host market through FDI. Nevertheless, this new competitive context can result in the need to reconfigure existing capabilities or acquire new ones (Zaheer, 1995). In this case, the firm may choose either to develop capabilities internally or buy them in the foreign market (Wernerfelt, 1984). If the firm needs to buy these new capabilities and they are difficult to find in the market due to information asymmetry or opportunism, acquisitions would be an efficient way to obtain these required capabilities. Otherwise, if the firm possesses those capabilities and has no incentive to acquire them, it can use them in the host country by a greenfield entry (Barkema \& Vermeulen, 1998). As a result, the level and nature of firmspecific advantages determines whether entry will be through acquisitions or greenfields (Hennart \& Park, 1993; Meyer, Estrin, Bhaumik \& Peng, 2009).

The Internalisation Theory, building on Transaction Cost Economics, analyses opportunism problems, limited rationality and transaction costs, and is complementary to the Resource-Based View of the firm (Anderson \& Gatignon, 1986; Buckley \& Casson, 1976, 1988). Firms will choose the entry mode that minimises the transaction costs associated with exploiting a competitive advantage in a foreign market (Buckley \& Casson, 1976; Dunning, 1988). Before acquiring a firm, two transaction costs need to be considered: those resulting from the valuation of the firm to be acquired, and the cost of integrating the acquired firm, as well as the possibility of acquiring unwanted assets. In general, these transaction costs increase with cultural or geographic distance, as obtaining information becomes more difficult (Kogut \& Singh, 1988). In this case, entry through greenfield involves lower transaction costs, and is therefore considered to be a more efficient mode of structuring intraorganisational exchanges than acquisitions (Brouthers \& Brouthers, 2000).

Finally, Institutional Theory plays a crucial role in entry mode decisions. Institutions support how market mechanisms operate, so institutional differences are highly significant for MNCs operating in multiple international contexts (Globerman \& Shapiro, 1999; Meyer \& Tran, 2006; Meyer et al., 2009). Formal rules make it possible to determine, for example, the entry mode allowed in each country, whereas informal rules may favour one particular mode over another (Peng, Wang \& Jiang, 2008). It also provides additional information about possible partners and their behaviour when establishing alliances. Essentially, a strong institutional framework equates to a lower cost in doing business (Bengoa \& Sanchez-Robles, 
2003; Bevan, Estrin \& Meyer, 2004; Estrin, 2002) or greater market efficiency (Kedia, Mukherjee \& Lahiri, 2006). Weak institutions reduce the possibility of choosing acquisitions due to a lack of transparency and information about host country's firms (Lin, Peng, Yang \& Sun, 2009). A weak institutional framework means increased costs and greater risk (Meyer et al., 2009). In emerging markets economies, institutions and institutional factors are particularly important because institutional weakness increases transaction costs and the level of risk that the firm must take on (Demirbag et al., 2008; Meyer \& Peng, 2005).

Based on these theoretical perspectives, various empirical studies analysed the influence of the specific conditions of the transaction, the organisational capabilities of the firm and the institutional framework on the establishment mode choice. The following are external and internal factors affecting the choice between acquisitions and greenfields.

\subsection{Cultural distance}

Cultural distance is a widely researched topic in the entry mode literature (Barkema, Bell \& Penning, 1996; Demirbag et al., 2007). According to Kogut and Singh (1988) and Hofstede (1989), cultural distance indicates differences in terms of culture, economic systems, and business practices between a home country and each individual host country. Cultural similarities between home and host country reduce transaction costs (Taylor, Zou \& Osland, 1998). There are costs associated with acquiring information about the local firm and costs of monitoring this information (Erramilli \& Rao, 1993). Coval and Moskowitz (2001) suggested that geographic and cultural proximity reduced the information costs about the acquisition. In other words, cultural distance increases information asymmetry, resulting in higher monitoring costs, and hampers the firm's ability to transfer core competencies to foreign markets (Tihanyi, Griffith \& Russell, 2005). Considering this, when cultural distance is high, greenfield ventures will be the preferred mode (Brouthers \& Brouthers, 2000; Tihanyi et al., 2005; Zhao, Luo \& Suh, 2004).

Furthermore, the greater the cultural distance, the higher the costs of transferring knowledge and technology (Almeida \& Kogut, 1999; Kogut \& Singh, 1988; Morschett, Schramm-Klein \& Swoboda, 2010). The acquired firm may even strongly resist knowledge transfer to the acquiring firm. In general, the larger the culture distance between the acquirer and the acquired unit, the more dissimilar and incompatible their practices and the more 
complicated their transfer (Cho \& Padmanabhan, 1995; Hofstede, 1980, 1983; Schneider \& De Meyer, 1991; Slangen, 2006). This has been supported by prior studies (Harzing, 2002; Kogut \& Singh, 1988; Larimo, 2003). Thus, we propose:

Hypothesis 1: Indian MNCs prefer to enter the host country through acquisitions when cultural distance between India and the host country is smaller.

\subsection{Host market attractiveness}

The attractiveness of a host market is another determining factor of entry mode choice (Demirbag et al., 2008; Morschett et al., 2010). Host market size increases the attractiveness for FDI (Chakraborty \& Basu, 2002). Faced with a growing market, MNCs tend to use a direct form of entry in order to achieve market share and obtain their own growth targets (Porter, 1980). Furthermore, markets with lower growth levels will provide more opportunities to acquire weaker competitors which are struggling with market conditions (Brouthers \& Brouthers, 2000). This leads us to propose:

Hypothesis 2: Indian MNCs prefer to enter the host country through acquisitions when the host market is less attractive.

\subsection{Host country risk}

Political risk is an important dimension of the institutional environment, particularly in the early stages until the company is adapted to the new location's rules (Demirbag et al., 2007). Countries with higher levels of risk tend to have more inefficient markets and possible corruption problems (Estrin, 2002). They also have insufficient protection of ownership rights, due to inefficient financial systems, restrictive regulations and high barriers to investment and commerce (Brouthers, 2002).

While MNCs may be able to take advantage of market imperfections, they may also have to deal with the high costs of uncertainty associated with these countries (Aybar \& Ficici, 2009; Quer, Claver \& Rienda, 2012). Moreover, transactions costs increase with bounded rationality, which makes it difficult to anticipate all possible contingencies. For this reason, internal development may help to reduce external uncertainty in high-risk countries (Kogut \& Singh, 1988; Klein, Frazier \& Roth, 1990). Furthermore, the Resource-Based View suggests that firms will prefer to preserve their resources by opting for internal development 
to avoid opportunism and to maintain control over the subsidiary (Agarwal \& Ramaswami, 1992). Therefore, when uncertainty is high, firms will not opt for acquisitions (Morschett et al., 2010). Thus, we propose:

Hypothesis 3: Indian MNCs prefer to enter the host country through acquisitions when there is a lower host country risk.

\subsection{Technological intensity of the industry}

Technology is a valuable firm-specific resource, as innovations may lead to a competitive advantage in the international market (Pradhan, 2004). Furthermore, technologyintensive industries attract high levels of FDI (Anand \& Delios, 2002).

When firms have a weak $R \& D$ base, the cost of internal development is high. Empirical evidence suggests that firms belonging to technology-intensive industries will prefer to set up in the host country using greenfield investments (Cho \& Padmanabhan, 1995; Hennart \& Park, 1993). There are two main reasons for such a choice (Barkema \& Vermeulen, 1998): firstly, to reduce chances of dissemination of firm-specific advantages and, secondly, because technologies are much easier to implement in a new firm than a preexisting one. Therefore, in technology-intensive industries such as telecommunications, firms are more likely to be able to develop in-house the technologies required for entry (Barkema \& Vermeulen, 1998; Lee \& Lieberman, 2010). These arguments lead us to propose:

Hypothesis 4: In less technology-intensive industries, Indian MNCs prefer to enter the host country through acquisitions.

\subsection{Previous experience in the host country}

Dynamic learning capabilities are resource-based advantages that facilitate adoption of new capabilities and adaptation of existing resources to changes in institutional environments. For international ventures, empirical research suggests that international experience may provide a firm with dynamic learning capabilities (Chang \& Rosenzweig, 2001); both the intensity and diversity of international experience endow a firm with resource-based advantages that can be used to exploit (or explore for) other resources in new markets (Luo \& Peng, 1999). 
The international experience accumulated by the firm is another factor that may affect the choice between acquisitions and greenfield investments. According to the KnowledgeBased View of the firm (Kogut \& Zander, 1993; Madhok, 1997), this decision is influenced by firm's experience. The strong effect of learning from prior experience in the internationalisation process supports the incremental experience of Uppsala's model (Johanson \& Vahlne, 1977; 1990), and this increases the likelihood of success in subsequent foreign market expansion (Barkema et al., 1996). As a result of this experience, firms will create organisational routines and knowledge that they can use in future investments, particularly if the investment is in the same country (Cho \& Padmanabhan, 1995; Brouthers \& Brouthers, 2000).

Transferring these routines will be much easier when the firm decides to enter a foreign market through greenfields. If the firm has prior investments in a host country, may be unnecessary to acquire a local firm. Therefore, if the firm lacks sufficient information about the host country, it will prefer to enter through acquisitions, in order to obtain local knowledge (Hennart \& Park, 1993). Thus, we propose:

Hypothesis 5: Indian MNCs prefer to enter the host country through acquisitions when they have less accumulated experience in that country.

\section{Methodology}

There was a rapid expansion of outward FDI from India during the 1990s (Buckley et al., 2012; Nayyar, 2008). Moreover, there was also an increase in the number of Indian firms entering host countries through acquisitions, for various reasons, such as market-seeking, strategic asset-seeking or natural resource-seeking (Pradhan, 2008). The period from 2000 to 2007 has been described as the arrival of Indian firms in developed countries and expanded Indian investment abroad (Singh \& Jain, 2009). Since 2001, understanding the process of the emergence of Indian companies as global players has attracted the attention of both academics and policy-makers.

It is difficult to find complete data and information on cross-border acquisitions from India. The Reserve Bank of India (RBI), the primary source of data on FDI, does not compile cross-border acquisitions data at firm level. Therefore, information on the specific establishment modes used by Indian MNCs has to be obtained from press reports or from web 
pages (Nayyar, 2008). For this reason, our study focuses on 91 companies of the Tata Group, one of the most representative MNCs in the country. The Tata Group publishes specific official data on its corporate website regarding investments made both in India and abroad. In order to test the hypotheses, entries into foreign markets by these 91 companies from 2000 to 2009 were selected for analysis.

\subsection{The Tata Group}

Investments in developed markets by Indian firms date back to 1961, when the Tata Group invested US\$ 7.4 million in Switzerland to establish its own subsidiary, Tata International AG, to represent the Group in European markets (Pradhan, 2008).

The Tata Group plays a central role in the Indian economy (Goldstein, 2008). This group has been studied and used as an example in many research works focusing on Indian MNCs (Balasubramanyam \& Forsans, 2010; Das, 2007; Gaur \& Kumar, 2009; Kumar, 2007; Nayyar, 2008; Pradhan \& Abraham, 2004; Rangan \& Parriño, 2008; Singh \& Jain, 2009). As table 1 reports, the Tata Group made seven out of the 25 most important cross-border acquisitions of Indian MNCs from 2000 to 2010. Four of them have been in the UK, two in the US and one in Singapore. Furthermore, the first and third most important acquisitions of Indian MNCs were those made by Tata Steel and Tata Motors, two firms of the Tata Group.

\section{Insert table 1 about here}

This large conglomerate is made up of around 100 firms, which operate in seven business sectors: communication and information technology, engineering, materials, services, energy, consumer products and chemicals. The Tata Group has operations in more than 80 countries, and on every continent. More specifically, total group revenues were US\$ 83.3 billion in the year $2010-2011$, with $58 \%$ of business coming from abroad. The firm has 425,000 employees worldwide.

Every firm in the Tata Group operates independently, and each one has its own board of directors and advisory board. Twenty-eight of them are publicly traded companies, with a market capitalisation of around US\$ 95.09 billion (as on February 16, 2012). The main firms are Tata Steel, Tata Motors, Tata Consultancy Services (TCS), Tata Power, Tata Chemicals, 
Tata Global Beverages, Indian Hotels, and Tata Communications. Tata Steel became the tenth-largest steel firm in the world following acquisition of Corus (after which the firm was renamed Tata Steel Europe). Tata Motors is the world's fifth-largest commercial vehicle manufacturer, and recently acquired Jaguar and Land Rover. TCS is a leading global software firm, with centres in the US, the UK, Hungary, Brazil, Uruguay and China, as well as India. Tata Global Beverages is the second-largest tea firm in the world, due to its British subsidiary Tetley. Tata Chemicals is the second-largest producer of soda ash in the world, and Tata Communications is one of the world's largest communications providers.

What makes the group peculiar, if not unique, is the fact that it is more than a simple financial holding, as it also centrally manages the Tata brand and provides high-level training (Goldstein, 2008). We chose this large business group for various reasons. The first is because Tata is one of the largest emerging market MNCs, and some of its firms are listed in prestigious business rankings such as Fortune Global 500 and Forbes. As stated above, about $30 \%$ of top 25 foreign acquisitions by Indian firms from 2000 to 2010 were made by Tata Group (Table 1). On the other hand, the Tata Group has a high level of unrelated diversification (Kedia, Mukherjee \& Lahiri, 2006). Thus, the second reason for choosing Tata is that it is a large conglomerate of firms in different sectors, which may be of interest as the behaviour of each individual firm can provide relevant information when considered as a whole. Finally, Tata's outlook has been outward-oriented from the very beginning and has an extensive international experience with operations in many countries.

\subsection{Data collection}

Data were obtained from various secondary sources. Data on each outward FDI were obtained from the corporate website of the Tata Group (www.tata.com). In order to enhance data reliability, we consulted other data sources, including the Centre for Monitoring Indian Economy, the Financial Times, the Business Standard, the Indian Express, Business Online India, and The Hindu Business Line. The final sample covered 117 outward FDIs into 43 countries made by 91 companies of the Tata Group between 2000 and 2009.

\subsection{Variables and measurement}


The dependent variable was the establishment mode chosen for each outward FDI, i.e. acquisitions or greenfields. Following Anand and Delios (2002), Barkema and Vermeulen (1998), Cho and Padmanabhan (1995), Hennart and Park (1993), Lee and Lieberman (2010), Slangen and Hennart (2008), Yip (1982) and Zejan (1990), a dummy variable takes a value of 1 if the company made an acquisition, and a value of 0 if it established a greenfield plant.

Regarding independent variables, cultural distance was first measured using the methodology developed by Kogut and Singh (1988), based on Hofstede (1980), which established four dimensions of national culture: power distance, uncertainty avoidance, masculinity/femininity and individualism. Countries with values close to 0 for cultural distance are culturally similar to India; high values for this distance mean a greater cultural gap with India. This variable has also been used by Aybar and Ficici (2009), Barkema and Vermeulen (1998), Cho and Padmanabhan (1995), Demirbag et al. (2007, 2008), Slangen (2006), and Slangen and Hennart (2008).

Cultural distance was also measured using a dummy variable with a value of 1 if the investment was made in Asia, where there is a greater cultural affinity with India, and 0 , otherwise. This alternative measurement of cultural distance has also been used by Azofra and Martínez (1999), Chang and Rosenzweig (2001) and Quer, Claver and Rienda (2007).

The gross domestic product (GDP) and GDP growth for the host country in the year prior to entry were used to measure market attractiveness (Barkema \& Vermeulen, 1998; Duanmu \& Guney, 2009). This information was obtained from the World Bank database. We used $\log$ transformation to normalise the distribution of these variables (Buckley, Clegg, Cross, Liu, Voss \& Zheng, 2007).

Host market risk was measured using the political risk ratio provided by the International Country Risk Guide report (PRS, 2009), which contains 22 variables in three categories (political, financial and economic) for measuring risk. PRS provides a separate index for each category. We focus on the Political Risk Rating, which includes 12 weighted variables covering both political and social attributes. This variable was interpreted in such a way that the greater the ratio, the lower the risk linked to that host country. This ratio has also been used in previous research (Buckley et al., 2007, 2009; Duanmu \& Guney, 2009).

To determine industry technological intensity, we used the OECD (2001) classification, which is based on the International Standard Industrial Classification (ISIC- 
revision 3). This measure has also been considered in other studies (Chen \& $\mathrm{Hu}, 2002$; Claver \& Quer, 2005). We created a variable with four categories to measure the industry technological intensity, as follows: 1-low technology-intensive industries, 2-medium-to-low technology-intensive industries, 3-medium-to-high technology-intensive industries, and 4high technology-intensive industries.

In accordance with Barkema and Vermeulen (1998), Kogut and Singh (1988), Meyer et al. (2009), and Slangen and Hennart (2008), international experience was measured using the number of previous entries into the host country. This information was obtained from each Tata firm's annual reports from its corporate website.

Finally, we considered two control variables. Firm size is a significant factor influencing international operations (Caves, 1996). In the case of Indian MNCs, firm size seems to have a positive effect on the likelihood that the firm will decide to invest in a foreign market (Kumar, 2007). Moreover, Transaction Cost Theory predicts a close relationship between firm size and the establishment mode, mainly through acquisitions, although empirical evidence is not conclusive. Thus, we controlled for firm size, which was measured using the logarithm of firm's revenues (Barkema \& Vermeulen, 1998; Cho \& Padmanabhan, 1995; Gaur \& Kumar, 2009).

Previous research on Indian firms identified a strong relationship between exports to a specific host country and FDI in the same country (Kumar, 2007; Pradhan, 2004). These exports may provide the investor with interesting information about the markets and the advantages of manufacturing abroad (Balasubramanyam \& Forsans, 2010). Thus, we considered the total exports made by India to the host country during the year prior to each entry as another control variable. This information was obtained from the Indian Government's Department of Commerce.

\section{Results and discussion}

\subsection{Main findings}

From the sample of 117 outward FDIs, 49 were acquisitions and 68 were greenfields. As occurred in previous studies on Indian MNCs (Balasubramanyam \& Forsans, 2010; Pradhan, 2008; Pradhan \& Abraham; 2004; Singh \& Jain, 2009), the main host countries were the US (18 entries), and the UK and China, with 10 entries each. If we analyse acquisitions 
alone, the US comes first, with 11 of the 49 acquisitions, followed by the UK and Australia, both with 5 acquisitions each. India is culturally very close to Western countries such as the US and the UK due to the proximity of the English language and the historic memory of India as a British colony. Greater familiarity with the language would therefore be one of the factors affecting this result.

The hypotheses were tested using a binomial logit model. The regression coefficients estimate the impact that the independent variables have on the probability of entry being through acquisitions, instead of greenfields. Table 2 shows the correlations between the independent variables included in the model, while table 3 summarises the results of the regression. As table 3 shows, the model is significant and predicts by a high percentage the establishment mode choice (70.9\%).

\section{Insert table 2 about here}

\section{Insert table 3 about here}

\subsection{Discussion}

The regression model does not support our first hypothesis, since no significant relationship exists between cultural distance and the establishment mode chosen. Although we hypothesised that greater cultural similarity was positively related to acquisitions, empirical evidence is not conclusive. Other studies found the opposite relationship (Barkema et al., 1996; Barkema \& Vermeulen, 1998) or did not report a significant effect (Brouthers \& Brouthers, 2000; Buckley et al., 2012; Cho \& Padmanabhan, 1995; Tihanyi et al., 2005). Meyer et al. (2009) failed to find a significant relationship for a group of firms from emerging countries, including India. Demirbag et al. (2008) reported a similar result for a group of Turkish MNCs. Furthermore, in a study of the main findings of various research papers, Morschett et al. (2010) found no empirical evidence for the relationship between culture distance and entry mode.

In our case, the lack of significance may be due to the fact that linkages and prior experience may be more important than cultural distance. A major source of ownership advantages for Indian firms is the know-how held by the Indian diaspora abroad (Balasubramanyam \& Forsans, 2010). As Buckley et al. (2012) found, "Indian expatriates act 
as cultural bridges to countries that are seemingly distant, thus ameliorating cultural distance". Moreover, local experience may help to reduce the risks associated with entry into culturally distant countries, which would lead MNCs to choose acquisitions, despite the wide cultural gap. Thus, with acquisitions, firms would reduce the cultural barriers through learning provided by the acquired firm (Chatterjee, 1990; Li, 1995).

In the case of India, Buckley et al. (2012) found that the relationship between cultural distance and Indian acquisitions might not be significant due to lack of economic integration and political rivalry within the South Asian countries. Asia is very diverse and India does not have good relationships with its neighbouring countries, and religious differences are some other things to consider.

Anyway, one of our measures of cultural distance was the Kogut and Singh (1988) index, which has come up insignificant in some earlier studies (Buckley et al., 2012). A potential problem about this measurement lies in the fact that, for some countries, no indicators in the index are available. We tried to overcome this difficulty by assigning these countries the score of others supposed to be culturally similar (Erramilli, 1991). Alternative measures of cultural distance could lead to different results. For example, similarly to what Buckley et al. (2007) did in the Chinese context, cultural proximity to India could be proxied by the percentage of ethnic Indian in the host population.

Some other factors may reduce the risk of cultural incompatibility or the costs of information and control. Previous experience in the host country may attenuate the effects of cultural distance, allowing the peculiarities of the local culture to be learned and reducing any problems that may arise due to the lack of information (Barkema \& Vermeulen, 1998; $\mathrm{Li}$, 1995). In fact, we obtained a negative and significant relationship between prior experience in the host country and the option of acquisition, which supports our fifth hypothesis.

We also found support for our second hypothesis, since host market attractiveness, measured by GDP growth, was significant and negatively associated with acquisitions. Although empirical evidence exists reporting a no significant relationship (Mudambi \& Mudambi, 2002), our finding is in line with previous studies suggesting that the greater the market growth in the host country, the greater the probability that the MNC will opt for a greenfield rather than an acquisition (Brouthers \& Brouthers, 2000; Larimo, 2003). Nevertheless, host market size is not significant in our model. A reason for this finding may 
be that the large number of competitors likely to be present in large markets might reduce the attractiveness of entry (Gomes-Casseres, 1990).

The third hypothesis is also supported. Lower risk in the host country has a significant positive influence on acquisitions. Thus, when there is a greater risk, firms perceive a greater uncertainty and will prefer to opt for greenfield investments, trying to avoid possible opportunism problems or know how transfer to competitors (Mudambi \& Mudambi, 2002). Buckley et al. (2009) suggested that political risk in the host country might not be a significant factor in cross-border acquisitions, for reasons such as India's experience and ability to work in such environments. However, our results indicate that for the Indian firms included in our sample, host country political risk influences establishment mode choice.

The fourth hypothesis predicted that firms operating in less technology-intensive industries would choose acquisitions instead of greenfields. MNCs that plan to transfer large amounts of firm-specific technological knowledge to their foreign subsidiaries often have a clear preference for greenfields, as such knowledge is easier to transfer to greenfield than to acquired firms (Hennart \& Park, 1993; Slangen \& Hennart, 2008). Our results support this hypothesis, since we obtained a negative and significant relationship between the technological intensity of the industry and acquisitions. Technology driven mergers and acquisitions have been a major channel of outward FDI from emerging economies, with the aim of accessing both the technological and marketing benefits. However, our findings suggest that Indian MNCs in technology-intensive industries would prefer to enter the host country by greenfields, with the aim of preserving its technology. This is the case of information technology and communications and engineering products and services sectors.

Anyway, the specific objective of each outward FDI decision (looking for resources, markets, or strategic assets) may influence these results. If the firm is looking for markets and it possesses advanced technology, it may prefer to keep its competitive advantages and choose greenfield investments, as we have found in our model. In other cases, when the firm seeks technology, acquisition may be the best option.

Regarding the control variables included in our model, firm size was not statistically significant. Although larger firms have the resources needed to purchase other firms, an opposite relationship is also feasible: large firms have enough resources to enter the host country by creating their own start-up firm. However, the other control variable proved to be 
significant. Indian exports to the host country are negatively associated with acquisitions. Prior contact through exports means that firms obtain certain information about the host market, the customers, the government, and so on, which helps them to choose a more independent form of entry into the local market.

\section{Conclusions}

The growth of cross-border acquisitions by Indian MNCs confirms their increasing presence in international markets. This paper has sought to analyse the determinants of the choice between acquisitions and greenfields by these MNCs.

Our results show that Indian MNCs prefer to enter the host country through greenfields when market growth is high, when there is a high political risk, when they belong to a technology-intensive industry, and when they have experience in the country. However, cultural distance is not a determining factor in the choice between acquisitions and greenfields.

Mixed conclusions can be drawn when comparing the results obtained here with those reported by other studies on MNCs from other countries. Technology-intensive industries are associated with MNCs entering the host market through greenfield investments, a result also found by Brouthers and Brouthers (2000), Cho and Padmanabhan (1995), and Hennart and Park (1993). Although cultural distance has also been associated with these establishment modes (Barkema \& Vermeulen, 1998; Harzing, 2002; Kogut \& Singh, 1988), some authors have obtained the same result as ours, finding no relationship (Brouthers \& Brouthers, 2000; Cho \& Padmanabahn, 1995). Regarding host country risk, Barkema and Vermeulen (1998) did not find a significant influence, though they suggested that the higher the risk, the greater the likelihood of choosing a joint venture. As stated above, our study found that the probability of opting for acquisitions is lower when there is a high host country political risk. To complete the external variables included in our model, market growth in the host country has not proven to be a variable with any clear tendency in previous research. Some results for Japanese firms suggested the option of acquisitions for more attractive markets (Hennart \& Park, 1993). However, another study found the opposite: a more attractive market is associated with greenfields (Brouthers \& Brouthers, 2000). 
One of the most widely used internal factor in the literature on entry modes is international experience. Although many studies suggest a non-significant relationship between experience and entry mode choice, empirical evidence is not conclusive. Thus, Japanese firms prefer internal development when they have more accumulated experience in the host country (Brouthers \& Brouthers, 2000). This is not the case for European firms, which tend to opt for acquisitions as their experience increases (Barkema \& Vermeulen, 1998). The results found here are more in line with those for Japanese firms.

\subsection{Contributions}

The choice between acquisitions and greenfields both entail benefits and costs for the host country. Acquisitions can have few benefits in terms of increased production capacity, employment or foreign market concentration, in such a way that the country's authorities may set restrictions for this establishment mode. However, these acquisitions can also provide the country with technological and managerial capabilities in the long term. Knowing which factors favour one or another establishment mode may therefore help the governments of these countries to improve how they co-ordinate their foreign promotion strategies.

In recent years, various authors have attempted to explain the internationalisation process of Indian firms from a macro vision of their outward FDIs (Balasubramanyam \& Forsans, 2010; Nayyar, 2008; Pradhan, 2008; Rangan \& Parriño, 2008; Singh \& Jain, 2009). However, these studies emphasise how important acquisitions are as establishment modes, albeit from a descriptive point of view. This paper has examined the factors that lead Indian firms to enter foreign markets through acquisitions, compared with the option of greenfield investments. By doing so, it has provided new empirical evidence for an issue that has received little attention for emerging economies, and has attempted to compare the results obtained in other studies with those found here.

\subsection{Limitations and future lines of research}

The first limitation of this paper concerns the variables included in our model. Although we considered some of the most researched factors in the entry mode literature, other variables may also affect the choice between acquisitions and greenfields. Future research applying these variables to a set of developing countries (including India) to detect 
whether influence varies by country of origin may help to increase the scope of the results obtained here.

A second limitation refers to the data used. Our empirical research is based on secondary data, a fact that influences the measurement of the variables. This prevented us from including managerial perceptions. Future studies could achieve a more in-depth understanding of the establishment mode choice of Indian MNCs by detailed surveys on managerial decision-making processes, including primary information from both the parent firm and the foreign subsidiaries.

Finally, when interpreting our results, it should be pointed out that our sample is based on the international operations of Tata Group companies. Although this is one of the most active Indian corporations in international markets, future research focusing on other Indian firms may lead to a greater knowledge of outward FDI decisions by Indian MNCs.

\section{References}

Agarwal, S. \& Ramaswami, S.N. (1992). Choice of foreign market entry mode: Impact of ownership, location and internalization factors. Journal of International Business Studies, 23 (1), 1-27.

Almeida, P. \& Kogut, B. (1999). Localization of knowledge and the mobility of engineers in regional networks. Management Science, 45 (7), 905-918.

Anand, J. \& Delios, A. (2002). Absolute and relative resources as determinants of international acquisitions. Strategic Management Journal, 23 (2), 119-134.

Anderson, E. \& Gatignon, H. (1986). Modes of foreign entry: A transaction cost analysis and propositions. Journal of International Business Studies, 17 (3), 1-26.

Anwar, A.I.; Hasse, R. \& Rabbi, F. (2008). Location determinants of Indian outward foreign direct investment: How multinationals choose their investments destinations? $C B S$ Conference on Emerging Multinationals, Copenhagen Business School, Denmark.

Arregle, J.-L.; Hebert, L. \& Beamish, P. (2006). Mode of international entry: The advantages of multilevel methods. Management International Review, 46 (5), 597-618. 
Aybar, B. \& Ficici, A. (2009). Cross-border acquisitions and firm value: An analysis of emerging-market multinationals. Journal of International Business Studies, 40 (8), 1317-1339.

Azofra, V. \& Martínez, A. (1999). Transactions costs and bargaining power: Entry mode choice in foreign markets. Multinational Business Review, 7 (1), 62-75.

Balasubramanyam, V.N. \& Forsans, N. (2010). Internationalisation drivers of Indian firms. Asian Business \& Management, 9 (3), 319-340.

Barkema, H.G. \& Vermeulen, F. (1998). International expansion through start-up or acquisitions: A learning perspective. Academy of Management Journal, 41 (1), 7-26.

Barkema, H.G.; Bell, J.H.J. \& Penning, J.M. (1996). Foreign entry, cultural barriers, and learning. Strategic Management Journal, 17 (2), 151-166.

Bengoa, M. \& Sanchez-Robles, B. (2003). Foreign direct investment, economic freedom and growth: New evidence from Latin America. European Journal of Political Economy, 19 (3), 529-545.

Bevan, A; Estrin, S. \& Meyer, K. (2004). Foreign investment location and institutional development in transition economies. International Business Review, 13 (1), 43-64.

Brouthers, K.D. (2002). Institutional, cultural and transaction cost influence on entry mode choice and performance. Journal of International Business Studies, 33 (2), 203-221.

Brouthers, K.D. \& Brouthers, L.E. (2000). Acquisition or greenfield start-up? Institutional, cultural and transaction cost influences. Strategic Management Journal, 21 (1), 89-97.

Buckley, P.J. \& Casson, M.C. (1976). The Future of the Multinational Enterprise. London: Macmillan.

Buckley, P.J. \& Casson, M.C. (1988). Analyzing foreign market entry strategies: Extending the internationalization approach. Journal of International Business Studies, 29 (3), 539-562.

Buckley, P.J.; Clegg, L.J.; Cross, A.R.; Liu, X.; Voss, H. \& Zheng, P. (2007). The determinants of Chinese foreign direct investment. Journal of International Business Studies, 38 (4), 499-518.

Buckley, P.J.; Forsans, N. \& Munjal, S. (2009). Foreign acquisitions by Indian multinational enterprises: A test of the Eclectic Paradigm. $35^{\text {th }}$ European International Business Academy Annual Conference (EIBA), Valencia, Spain. 
Buckley, P.J.; Forsans, N. \& Munjal, S. (2012). Host-home country linkages and host-home country specific advantages as determinants of foreign acquisitions by Indian firms. International Business Review, forthcoming.

Capron, L.; Dussauge, P. \& Mitchell, W. (1998). Resource redeployment following horizontal acquisitions in Europe and North America, 1988-1992. Strategic Management Journal, 19 (7), 631-661.

Caves, R.E. (1996). Multinational Enterprise and Economic Analysis. Cambridge: Cambridge University Press.

Chakraborty, C. \& Basu, P. (2002). Foreign direct investment and growth in India: A cointegration approach. Applied Economics, 34 (9), 1061-1073.

Chang, S.J. \& Rosenzweig, P.M. (2001). The choice of entry mode in sequential foreign direct investment. Strategic Management Journal, 22 (8), 747-76.

Chatterjee, S. \& Lubatkin, M. (1990). Corporate mergers, stockholder diversification, and changes in systematic risk. Strategic Management Journal, 11 (4), 255-268.

Chatterjee, S. \& Wernerfelt, M. (1991). The link between resources and type of diversification: Theory and evidence. Strategic Management Journal, 12 (1), 33-48.

Chatterjee, S. (1990). Excess resources, utilization cost, and mode of entry. Academy of Management Journal, 33 (4), 780-800.

Chen, H \& Hu, M.Y. (2002). An analysis of determinants of entry mode and its impact on performance. International Business Review, 11 (2), 193-210.

Cho, K.R. \& Padmanabhan, P. (1995). Acquisitions versus new venture: The choice of foreign establishment mode by Japanese firms. Journal of International Management, $1(3), 255-285$.

Claver, E. \& Quer, D. (2005). Choice of market entry mode in China: The influence of firmspecific factors. Journal of General Management, 30 (3), 51-70.

Coval, J.D. \& Moskowitz, T.J. (2001). The geography of investment: Informed trading and asset prices. The Journal of Political Economy, 109 (4), 811-841.

Das, N. (2007): The emergence of Indian multinationals in the new global order. International Journal of Indian Culture and Business Management, 1 (1/2), 136-150. 
Demirbag, M.; Glaister, K.W. \& Tatoglu, E. (2007). Institutional and transaction cost influences on MNEs' ownership strategies of their affiliates: Evidence from an emerging market. Journal of World Business, 42 (4), pp. 418-434.

Demirbag, M.; Tatoglu, E. \& Glaister, K.W. (2008). Factors affecting perceptions of the choice between acquisition and greenfield entry: The case of western FDI in an emerging market. Management International Review, 48 (1), 5-38.

Duanmu, J.L. \& Guney, Y. (2009). A panel data analysis of locational determinants of Chinese and Indian outward foreign direct investment. Journal of Asia Business Studies, 3 (2), 1-15.

Dunning, J.H (1988). The eclectic paradigm of international production: A restatement and some possible extensions. Journal of International Business Studies, 19 (1), 1-31.

Dunning, J.H. (1993). Multinational Enterprises and the Global Economy. Addison-Wesley. Publishing Company, New York.

Dutz, M.A. (1989). Horizontal mergers in declining industries: Theory and evidence. International Journal of Industrial Organization, 7 (1), 11-33.

Erramilli, M.K. (1991). The experience factor in foreign market entry behavior of service firms. Journal of International Business Studies, 22(3), 479-501.

Erramilli, M.K. \& Rao, C.P. (1993). Service firms' international entry-mode choice: A modified transaction-cost analysis approach. Journal of Marketing, 57 (3), 19-38.

Estrin, S. (2002). Competition and corporate governance in transition. Journal of Economic Perspective, 16 (1), 101-124.

Gammeltoft, P.; Pradhan, J.P. \& Goldstein, A. (2010). Emerging multinationals: Home and host country determinants and outcomes. International Journal of Emerging Markets, $5(3 / 4), 254-265$.

Gaur, A.S. \& Kumar, V. (2009). International diversification, business group affiliation and firm performance: Empirical evidence from India. British Journal of Management, 20 (2), 172-186.

Globerman, S. \& Shapiro, D.M. (1999). The Impact of government policy on foreign direct investment: The Canadian experience. Journal of International Business Studies, 30 (3), 513-532. 
Goldstein, A. (2008). The internationalization of Indian companies: The case of Tata. Centre for the Advanced Study of India, Working Paper Series, $n^{\circ}$ 08-02.

Gomes-Casseres, B. (1990). Firm ownership preferences and host government restrictions: An integrated approach. Journal of International Business Studies, 21 (1), 1-22.

Gubbi, S.R.; Aulakh, P.R.; Ray, S.; Sarkar, M.B. \& Chittoor, R. (2010). Do international acquisitions by emerging-economy firms create shareholder value? The case of Indian firms. Journal of International Business Studies, 41 (3), 397-418.

Harzing, A-W. (2002). Acquisitions versus greenfields investments: International strategy and management of entry modes. Strategic Management Journal, 23 (3), 211-227.

Hennart, J-H \& Park, Y-R. (1993). Greenfield vs. acquisitions: The strategy of Japanese investors in the United States. Management Science, 39 (9), 1054-1070.

Hofstede, G. (1980). Culture's Consequences: International Differences in Work-related Values. Beverly Hills: Sage Publications.

Hofstede, G. (1983). The cultural relativity of organizational practices and theories. Journal of International Business Studies, 14 (2), 75-89.

Hofstede, G. (1989). Organising for cultural diversity. European Management Journal, 7 (4), 390-397.

Jensen, M. (1986). Agency costs of free cash flow, corporate finance and takeovers. American Economic Review, 76 (2), 323-329.

Johanson, J. \& Vahlne, J.E. (1977). The internationalization process of the firm- A model of knowledge development and increasing foreign market commitment. Journal of International Business Studies, 8 (1), 22-32.

Johanson, J. \& Vahlne, J.E. (1990). The mechanism of internationalisation. International Marketing Review, 7 (4), 11-24.

Kedia, B.L.; Mukherjee, D. \& Lahiri, S. (2006). Indian business groups: Evolution and transformation. Asia Pacific Journal of Management, 23 (4), 559-577.

Klein, S.; Frazier, G.L. \& Roth, V.J. (1990). A transaction cost analysis model of channel integration in international markets. Journal of Marketing Research, 27 (2), 196-208.

Kogut, B. \& Singh, U. (1988). The effect of national culture on the choice of entry mode. Journal of International Business Studies, 19 (3), 411-432. 
Kogut, B. \& Zander, U. (1993). Knowledge of the firm and the evolutionary theory of the multinational corporation. Journal of International Business Studies, 24 (4), 625-645.

Kumar, N. (2007). Emerging TNCs: Trends, patterns and determinants of outward FDI by Indian enterprises. Transnational Corporations, 16 (1), 1-26.

Kumar, S. \& Bansal, L.K. (2008). The impact of mergers and acquisitions on corporate performance in India. Management Decision, 46 (10), 1531-1543.

Larimo, J. (2003). Form of investment by Nordic firms in world markets. Journal of Business Research, 56 (10), 791-803.

Lee, G.K. \& Lieberman, M.B. (2010). Acquisition vs. internal development as mode of market entry. Strategic Management Journal, 31 (2), 140-158.

Li, J. (1995). Foreign entry and survival: Effects on strategic choices on performance in international markets. Strategic Management Journal, 16 (5), 333-351.

Lin, Z.; Peng, M.W.; Yang, H. \& Sun, S.L. (2009). How do networks and learning drive M\&As? An institutional comparison between China and the United States. Strategic Management Journal, 30 (10), 1113-1132.

Luo, Y. \& Peng, M.W. (1999). Learning to compete in a transition economy. Journal of International Business Studies, 30 (2), 269-295.

Madhok, A. (1997). Cost, value and foreign market entry mode: The transaction and the firm. Strategic Management Journal, 18 (1), 39-61.

Meyer, K.E. \& Peng, M.W. (2005). Probing theoretically into central and eastern Europe: Transactions, resources, and institutions. Journal of International Business Studies, 36 (6), 600-621.

Meyer, K.E. \& Tran, Y.T.T. (2006). Market penetration and acquisition strategies for emerging economies. Long Range Planning, 39 (2), 177-197.

Meyer, K.E.; Estrin, S.; Bhaumik, S.K. \& Peng, M.W. (2009). Institutions, resources, and entry strategies in emerging economies. Strategic Management Journal, 30 (1), 61-80.

Morschett, D.; Schramm-Klein, H \& Swoboda, B. (2010). Decades of research on market entry modes: What do we really know about external antecedents of entry mode choice? Journal of International Management, 16 (1), 60-77.

Mudambi, R. \& Mudambi, S.M. (2002). Diversification and market entry choices in the context of foreign direct investment. International Business Review, 11 (1), 35-55. 
Nayyar, D. (2008). The internationalization of firms from India: Investment, mergers and acquisitions. Oxford Development Studies, 36 (1), 111-131.

Peng, M.W.; Wang, D.Y.L. \& Jiang, Y. (2008): An institution-based view of international business strategy: A focus on emerging economies. Journal of International Business Studies, 39 (5), 920-936.

Porter, M.E. (1980). Competitive Strategy. The Free Press: New York.

Pradhan, J.P. (2004). The determinants of outward foreign direct investment: A firm-level analysis of Indian manufacturing. Oxford Development Studies, 32 (4), 619-639.

Pradhan, J.P. (2008). Indian direct investment in developed regions. CBS Conference on Emerging Multinationals, Copenhagen Business School, Denmark.

Pradhan, J.P. \& Abraham, V. (2004). Overseas mergers and acquisitions by Indian enterprises: Patterns and motivations. MPRA Paper $n^{o}$ 17076. Online at http://mpra.ub.uni-muenchen.de/17076/.

PRS (2009). International country risk guide (ICRG). The Political Risk Services Group. http://www.prsgroup.com/.

Quer, D.; Claver, E. \& Rienda, L. (2007). The impact of country risk and cultural distance on entry mode choice: An integrated approach. Cross-Cultural Management: An International Journal, 14 (1), 74-87.

Quer, D.; Claver, E. \& Rienda, L. (2012). Political risk, cultural distance, and outward foreign direct investment: Empirical evidence from large Chinese firms. Asia Pacific Journal of Management, forthcoming.

Rangan, U.S. \& Parriño, J.D. (2008). Going abroad through acquisitions: An exploratory analysis of Indian companies' recent international expansion. International Journal of Indian Culture and Business Management, 1 (3), 335-353.

Schneider, S.C. \& De Meyer, A. (1991). Interpreting and responding to strategic issues: The impact of national culture. Strategic Management Journal, 13 (4), 307-320.

Seth, A. (1990). Sources of value creation in acquisition: An empirical investigation. Strategic Management Journal, 11 (6), 431-447.

Singh, S. (2009). International acquisitions by Indian firms- synergy, agency or hubris? AIB Annual Meeting, San Diego, California. 
Singh, L. \& Jain, V. (2009). Emerging pattern of India's outward foreign direct investment under influence of state policy: A macro view. MPRA Paper $n^{o} 13439$. Online at http://mpra.ub.uni-muenchen.de/13439/.

Slangen, A.H.L. \& Hennart, J.F. (2008). Do multinationals really prefer to enter culturally distant countries through greenfields rather than through acquisitions? The role of parent experience and subsidiary autonomy. Journal of International Business Studies, 39 (3), 472-490.

Slangen, A.H.L. (2006). National cultural distance and initial foreign acquisition performance: The moderating effect of integration. Journal of World Business, 41 (2), 161-170.

Stigler, G.J. (1964). A theory of oligopoly. Journal of Political Economy, 72 (1), 44-61.

Taylor, C., Zou, S. \& Osland, G. (1998). A transaction cost perspective on foreign market entry strategies of US and Japanese firms. Thunderbird International Business Review, 40 (4), 389-412.

Tihanyi, L., Griffith, D.A. \& Russell, C.J. (2005). The effect of cultural distance on entry mode choice, international diversification, and MNE performance: A meta-analysis. Journal of International Business Studies, 36 (3), 270-283.

UNCTAD (2010). World Investment Report 2010. Investing in a Low-Carbon Economy. New York and Geneva: United Nations Conference on Trade and Development.

UNCTAD (2011). World Investment Report 2011. Non-equity modes of international production and development. New York and Geneva: United Nations Conference on Trade and Development.

Wernerfeld, B. (1984). A resource-based view of the firm. Strategic Management Journal, 5 (2), 171-180.

Yip, G.P. (1982). Diversification entry: Internal development versus acquisition. Strategic Management Journal, 3 (4), 331-345.

Zaheer, S. (1995). Overcoming the liability of foreignness. Academy of Management Journal, $38,341-363$.

Zejan, M.C. (1990). New ventures or acquisitions. The choice of swedish multinational enterprises. The Journal of Industrial Economics, 38 (3), 349-355. 
Laura Rienda , Enrique Claver \& Diego Quer (2013): The internationalisation of Indian multinationals: determinants of expansion through acquisitions, Journal of the Asia Pacific Economy, 18:1, 115-132

To link to this article: http://dx.doi.org/10.1080/13547860.2012.742705

Zhao, H.; Luo, Y. \& Suh, T. (2004). Transaction cost determinants and ownership-based entry mode choice: A meta-analytical review. Journal of International Business Studies, 35 (6), 524-544. 
Laura Rienda , Enrique Claver \& Diego Quer (2013): The internationalisation of Indian multinationals: determinants of expansion through acquisitions, Journal of the Asia Pacific Economy, 18:1, 115-132

To link to this article: http://dx.doi.org/10.1080/13547860.2012.742705

\section{Tables}

\section{Table 1}

Top 25 foreign acquisitions by Indian firms from 2000 to 2010

\begin{tabular}{|c|c|c|c|c|c|c|}
\hline Rank & Year & Indian firm & Target firm & Country & Industry & $\begin{array}{c}\text { Value } \\
\text { (US \$ million) }\end{array}$ \\
\hline 1 & 2007 & Tata Steel & Corus Steel & UK & Steel & 12,100 \\
\hline 2 & 2007 & Hindalco & Novelis & US & Aluminium & 6,000 \\
\hline 3 & 2008 & Tata Motors & Jaguar and Land Rover brands & UK & Engineering & 2,300 \\
\hline 4 & 2006 & ONGC Videsh & Petrobas & Brazil & Petroleum & 1,400 \\
\hline 5 & 2002 & ONGC Videsh & Greater Nile Oil Project & Sudan & Petroleum & 766.1 \\
\hline 6 & 2006 & $\begin{array}{c}\text { Tata Tea and Tata } \\
\text { Sons }\end{array}$ & Glaceau & US & Health drinks & 677 \\
\hline 7 & 2004 & ONGC Videsh & Greater Plutonio Project & Angola & Petroleum & 600 \\
\hline 8 & 2004 & Opto Circuits India Ltd & Eurocor $\mathrm{GmbH}$ & Germany & Medical equipment & 600 \\
\hline 9 & 2006 & Dr. Reddy's & Betapharm Arzneimittel GmbH & Germany & $\begin{array}{l}\text { Pharmaceuticals and } \\
\text { healthcare }\end{array}$ & 570.3 \\
\hline 10 & 2006 & Suzlon Energy & Hansen Transmissions & Belgium & Energy & 565 \\
\hline 11 & 2006 & Kraft Food Ltd & United Biscuits & UK & Food and beverages & 522 \\
\hline 12 & 2008 & $\begin{array}{l}\text { Tata Consultancy } \\
\text { Services }\end{array}$ & Citigroup Global Services & UK & Information technology & 512 \\
\hline 13 & 2000 & Tata Tea & Tetley Group & UK & Food and beverages & 431.2 \\
\hline 14 & 2006 & $\begin{array}{c}\text { Ranbaxy Laboratories } \\
\text { Ltd }\end{array}$ & Terapia SA & Romania & $\begin{array}{c}\text { Pharmaceuticals and } \\
\text { healthcare }\end{array}$ & 324 \\
\hline 15 & 2000 & ONGC Videsh & Sakhalin-I PSA Project & Russia & Petroleum & 323 \\
\hline 16 & 2005 & Ispat Industries Ltd & Finmetal Holdings & Bulgaria & Steel & 300 \\
\hline 17 & 2005 & Videocon International & Thomson SA (CRT business) & $\begin{array}{l}\text { Europe, } \\
\text { China }\end{array}$ & Consumer goods & 289.2 \\
\hline 18 & 2004 & Tata Steel & NatSteel Asia Pte. & Singapore & Steel & 283.7 \\
\hline 19 & 2005 & VSNL Ltd & $\begin{array}{l}\text { Teleglobe International Holdings } \\
\text { Ltd }\end{array}$ & US & Telecom & 254.3 \\
\hline 20 & 2005 & Mtrix Laboratories & Docpharma NV & Belgium & $\begin{array}{c}\text { Pharmaceuticals and } \\
\text { healthcare }\end{array}$ & 234.7 \\
\hline 21 & 2006 & Tata Coffee & Eight O'Clock Coffee Co. & US & Food and Beverages & 220 \\
\hline 22 & 2006 & $\begin{array}{c}\text { Susken Communication } \\
\text { Tech Ltd }\end{array}$ & Bornia Hightec & Finland & Information technology & 210 \\
\hline 23 & 2006 & Ballarpur Industries Ltd & Sabah Forest Industries & Malyasia & Pulp and paper & 209 \\
\hline 24 & 2003 & Reliance Infocomm & Flag Telecom & US & Telecom & 191.2 \\
\hline 25 & 2006 & Seagate Tech Ltd & Evault Inc. & US & Information technology & 185 \\
\hline
\end{tabular}


Laura Rienda , Enrique Claver \& Diego Quer (2013): The internationalisation of Indian multinationals: determinants of expansion through acquisitions, Journal of the Asia Pacific Economy, 18:1, 115-132

To link to this article: http://dx.doi.org/10.1080/13547860.2012.742705

Table 2

Bivariate correlations

\begin{tabular}{|c|c|c|c|c|c|c|c|c|}
\hline \multirow{2}{*}{ 1. Cultural distance (Kogut \& Singh) } & 1 & 2 & 3 & 4 & 5 & 6 & 7 & 8 \\
\hline & & & & & & & & \\
\hline 2. Cultural distance (Asia vs. other countries) & $-0.26 * *$ & & & & & & & \\
\hline 3. Host market size & 0.09 & $-0.19 *$ & & & & & & \\
\hline 4. Host market growth & $-0.31 * *$ & $0.52 * *$ & $-0.38 * *$ & & & & & \\
\hline 5. Political risk & $0.22 *$ & $-0.23 *$ & $0.44^{* *}$ & $-0.36 * *$ & & & & \\
\hline 6. Technological intensity of the industry & $0.19 *$ & -0.13 & 0.07 & -0.11 & 0.07 & & & \\
\hline 7. Previous experience in the host country & -0.12 & -0.17 & 0.01 & $-0.25 * *$ & 0.00 & 0.00 & & \\
\hline 8. Firm size & $0.29 * *$ & -0.10 & -0.18 & 0.01 & -0.10 & $0.34 * *$ & 0.13 & \\
\hline 9. Exports to the host country & -0.04 & 0.15 & $0.63 * *$ & $-0.24 * *$ & $0.29 * *$ & -0.08 & 0.00 & $-0.25 *$ \\
\hline
\end{tabular}

$\mathrm{N}=117$

$* * \mathrm{p}<0.01 ; * \mathrm{p}<0.05$

Table 3

Logistic regression results

\begin{tabular}{lcc}
\hline \multicolumn{1}{c}{ Variables } & \multicolumn{1}{c}{$\beta$} & $S E$ \\
Cultural distance (Kogut \& Singh) (H1) & -0.58 & 0.06 \\
Cultural distance (Asia vs. other countries) (H1) & -0.19 & 0.66 \\
Host market size (H2) & 0.54 & 0.40 \\
Host market growth (H2) & $-2.10^{*}$ & 0.99 \\
Political risk (H3) & $0.05^{*}$ & 0.02 \\
Technological intensity of the industry (H4) & $-0.56^{*}$ & 0.18 \\
Previous experience in the host country (H5) & $-0.02^{*}$ & 0.01 \\
Firm size (Control) & -0.05 & 0.35 \\
Exports to the host country (Control) & $-1.20^{*}$ & 0.56 \\
Chi-square & \multicolumn{2}{c}{$119.92 * *$} \\
Cox \& Snell pseudo R & \multicolumn{2}{c}{0.26} \\
\hline Percentage correctly classified & \multicolumn{2}{c}{$70.9 \%$} \\
\hline $\mathrm{N}$ & \multicolumn{2}{c}{117} \\
\hline p $<0.05, * * \mathrm{p}<0.01$ & \multicolumn{3}{c}{}
\end{tabular}

